\title{
Formal definition of the Lower Jurassic McCoy Brook Formation, Fundy Rift Basin, eastern Canada
}

\author{
Lawrence H. Tanner \\ Department of Geography and Earth Science, Bloomsburg University, \\ Bloomsburg, Pennsylvania 17815, U.S.A.
}

Date Received July 24, 1995

Date Accepted February 29, 1996

\begin{abstract}
The name McCoy Brook Formation, presently in informal use, is formally proposed to designate outcrops of Lower Jurassic (Hettangian-Pliensbachian) strata overlying the North Mountain Basalt in the structural Minas Subbasin of the Fundy Rift Basin. It is also proposed that this designation be extended to include stratigraphically equivalent strata beneath the Bay of Fundy throughout the entire Fundy Rift Basin. It is further recommended that use of the name Scots Bay Formation, the current designation for post-basalt Jurassic sediments outcropping on the south side of the Minas Subbasin, be discontinued. The name Scots Bay Member of the McCoy Brook Formation is used here to designate distinctive lacustrine strata at the base of the McCoy Brook Formation outcropping on both sides of the Minas Subbasin.

On propose officiellement le nom de Formation de McCoy Brook, qui est présentement utilisé de manière officieuse, pour désigner les affleurements ou les strates du Jurassique inférieur (Hettangien-Pliensbachien) recouvrant le basalte du mont North dans le sous-bassin structurel Minas du bassin d'effondrement Fundy. Il est en outre proposé que l'on étende ce nom pour qu'il englobe les strates stratigraphiquement équivalentes sous la baie de Fundy dans l'ensemble du bassin d'effondrement Fundy. Il est par ailleurs recommandé que l'on cesse d'utiliser le nom de Formation de Scots Bay, nom actuel de l'affleurement de sédiments du Jurassique postérieur au basalte sur la rive sud du sous-bassin Minas. On utilise ici le nom de membre Scots Bay de la Formation de McCoy Brook pour désigner les strates lacustres caractéristiques à la base de l'affleurement de la Formation de McCoy Brook sur les deux rives du sous-basin Minas.
\end{abstract}

[Traduit par la rédaction]

\section{INTRODUCTION}

Limited exposures of post-North Mountain Basalt (Jurassic) sedimentary strata occur as coastal exposures on the north and south sides of the structural Minas Subbasin (sensu Olsen and Schlische, 1990), overlain largely by the waters of the geographic Minas Basin, Minas Channel and Cobequid Bay (Fig. 1). The term Scots Bay Formation is well established in reference to strata on the south side of the subbasin. Although the designation McCoy Brook Formation is in wide usage for equivalent strata on the north side of the subbasin (Olsen, 1981; Hubert and Mertz, 1984; Olsen et al., 1987, 1989; Olsen and Schlische, 1990; Tanner and Hubert, 1991, 1992; Smoot, 1991; Greenough, 1995; Withjack et al., 1995), some authors use the term Scots Bay to refer to the same strata called McCoy Brook by others (Stevens, 1980, 1987; Williams et al., 1985). This ambiguity continues offshore. Jurassic strata beneath the Bay of Fundy examined by wells or seismic reflection are referred to alternately as McCoy Brook or Scots Bay equivalent (Olsen and Schlische, 1990; Brown and Grantham, 1992).

This paper proposes: (1) that the McCoy Brook Formation be formally recognized as the designation for all postNorth Mountain Basalt sedimentary strata outcropping in the Minas Subbasin, with the type section west of McKay
Head on the north shore of the geographic Minas Basin; (2) that this designation include equivalent post-North Mountain Basalt strata beneath the Bay of Fundy throughout the Fundy Rift Basin (sensu Olsen and Schlische, 1990); and (3) that the distinctive lacustrine facies at the base of the formation be designated the Scots Bay Member, with the type section at East Broad Cove on the Blomidon Peninsula (the type section for the current Scots Bay Formation).

\section{Geologic Setting}

The Fundy Rift Basin complex comprises three faultbounded subbasins: the Fundy and Chignecto subbasins, bordered to the northwest by southeast dipping normal faults, and the transtensional Minas Subbasin, bounded to the north by the left-oblique Cobequid-Chedabucto fault (Fig. 2) (Olsen and Schische, 1990; Brown and Grantham, 1992; Withjack et al., 1995). The Fundy Group of the Newark Supergroup comprises the Mesozoic formations of the Fundy Rift Basin, which formed during the early Mesozoic breakup of Pangaea. The stratigraphy of the Minas Subbasin as presently defined is illustrated in Table 1. Sedimentation in the subbasin began during the Middle Triassic as the $360 \mathrm{~m}$ (in the type area) Wolfville Formation redbeds of fluvial, alluvial-fan and eolian origin were deposited unconformably on Palacozoic 


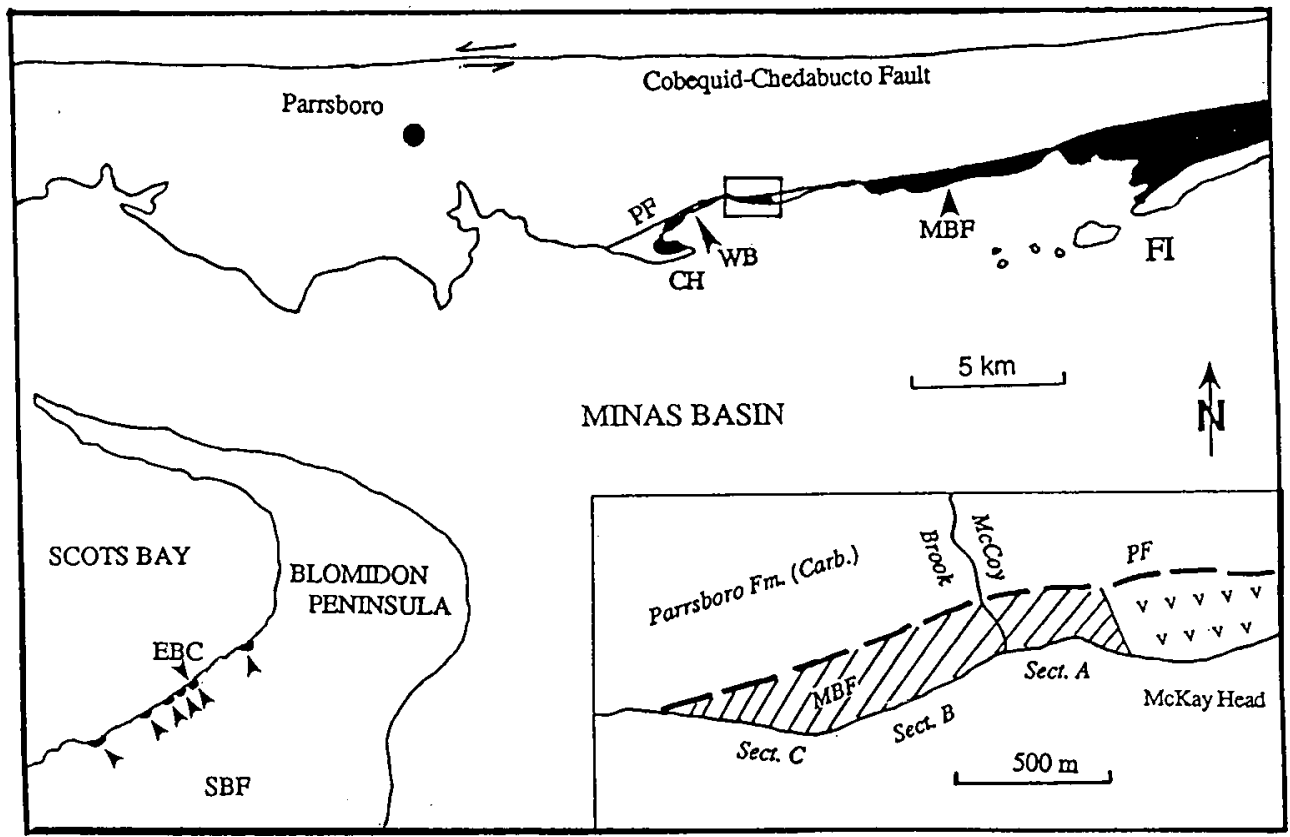

Fig. 1. Simplified geological map of a portion of the Minas Subbasin illustrating areas of outcrop of the McCoy Brook Formation (MBF - shaded black) and Scots Bay Formation (SBF). Arrows point to approximate location of Scots Bay outcrops. EBC = East Broad Cove, the type section location for the Scots Bay Formation. The inset box shows the location of the McCoy Brook type section west of the basalt head land at McKay Head. $\mathrm{CH}=$ Clark Head, PF = Portapique Fault, WB = Wasson Bluff, FI = Five Islands.

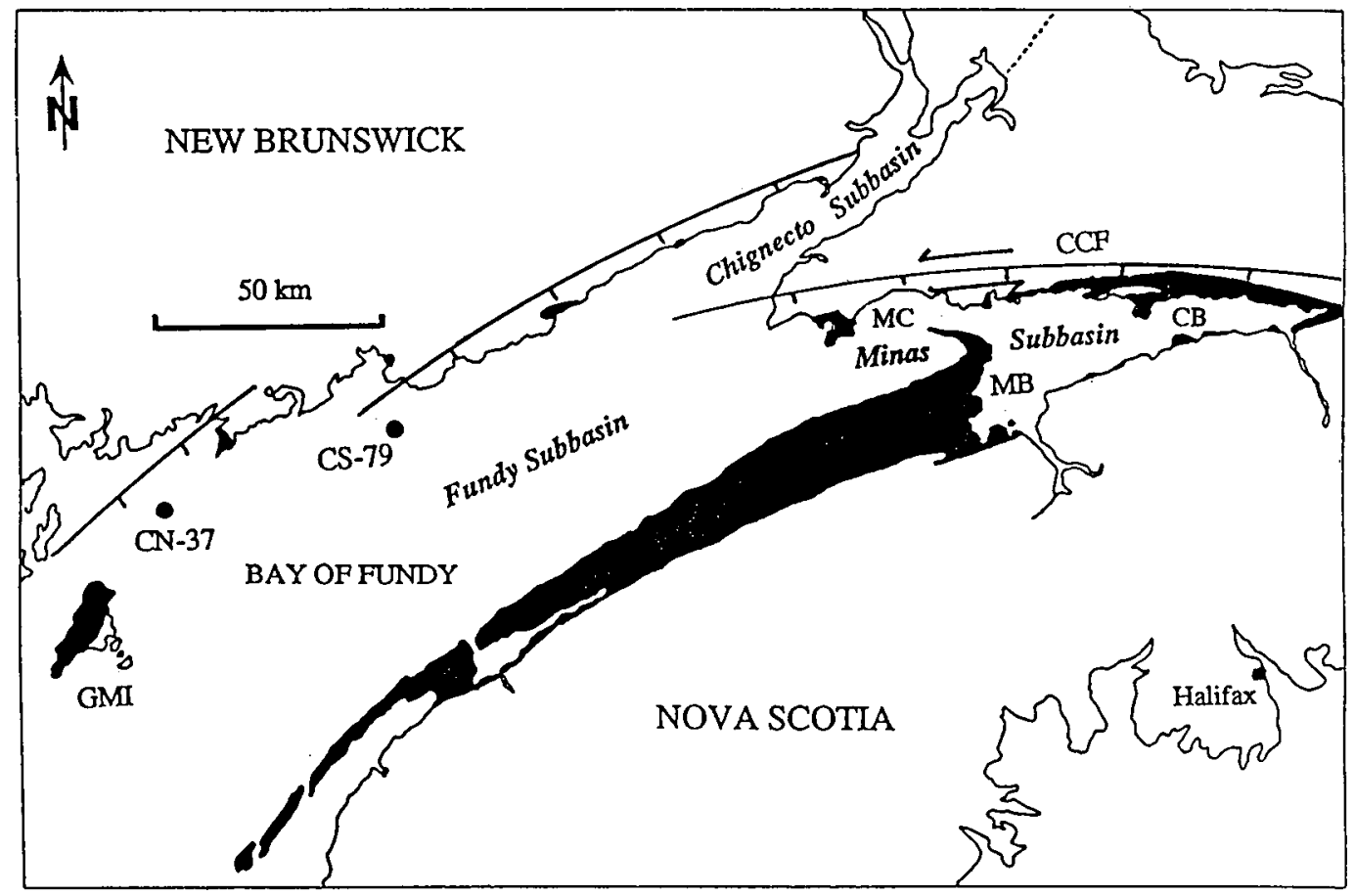

Fig. 2. Generalized map of the Fundy Rift Basin and component subbasins. Areas of Mesozoic outcrop are shaded black. GMI $=$ Grand Manan Island, CN-37 = Chinampas N-37 well location, CS-79 = Cape Spencer \#79 well location, CCF = Cobequid-Chedabucto Fault, $\mathrm{MB}=$ Minas Basin, $\mathrm{CB}=$ Cobequid Bay, $\mathrm{MC}=$ Minas Channel. 
Table 1. Stratigraphy presently defined for Fundy Group in the Minas Subbasin and offshore equivalents. Note: Triassic stratigraphy for New Brunswick outcrops in the Fundy and Chignecto subbasins differs.

\begin{tabular}{|c|c|c|c|c|c|}
\hline \multicolumn{2}{|c|}{ AGE } & \multirow{2}{*}{ Formation Name } & \multicolumn{3}{|c|}{ Maximum Thicknesses } \\
\hline \multirow{4}{*}{$\begin{array}{l}U \\
H \\
\text { U } \\
\text { 足 } \\
\text { 吕 } \\
\text { D }\end{array}$} & TOARCIAN & & $\begin{array}{l}\text { Onshore } \\
\text { Minas Subbasin }\end{array}$ & $\begin{array}{l}\text { *Chinampas } \\
\text { Well }\end{array}$ & $\begin{array}{l}\text { ^Seismic } \\
\text { Sections }\end{array}$ \\
\hline & PLIENSBACHIAN & MCCOY BROOK FORMATION & $230+m$ & \multirow[t]{2}{*}{$357 \mathrm{~m}$} & \multirow[t]{2}{*}{$3000 \mathrm{~m}$} \\
\hline & \multirow[b]{2}{*}{ HETTANGIAN } & SCOTS BAY FM. & $9 \mathrm{~m}$ & & \\
\hline & & NORTH MOUNTAIN BASALT & $300 \mathrm{~m}$ & $333 \mathrm{~m}$ & $600 \mathrm{~m}$ \\
\hline \multirow{4}{*}{ 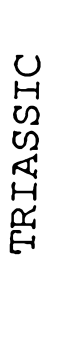 } & NORIAN & BLOMIDON FORMATION & $365 \mathrm{~m}$ & $1168 \mathrm{~m}$ & $2500 \mathrm{~m}$ \\
\hline & CARNIAN & \multirow{2}{*}{ WOLFVILLE FORMATION } & \multirow{2}{*}{$833 \mathrm{~m}$} & \multirow{2}{*}{$1708+m$} & \multirow{2}{*}{$3000+m$} \\
\hline & LADINIAN & & & & \\
\hline & ANISIAN & Pre-Mesozoic unconformity & & & \\
\hline
\end{tabular}

strata (Hubert and Forlenza, 1988). The $315 \mathrm{~m}$ (in the type area) Blomidon Formation of Late Triassic to Early Jurassic age, comprising predominantly playa mudstone, playalake claystone and sandflat sandstone, conformably overlies the Wolfville Formation (Mertz and Hubert, 1990). The Triassic-Jurassic boundary is defined by palynology in the uppermost Blomidon Formation (Olsen et al., 1989). Deposition of terrestrial sediments was interrupted during the Early Jurassic by eruption of 100 to $300 \mathrm{~m}$ of tholeiitic basalt flows of the North Mountain Basalt, dated at $202 \pm 2$ ma (Hodych and Dunning, 1992). Sedimentation resumed during the Early Jurassic with deposition of limestones, mudstones, cherts, and sandstones, formerly called the Scots Bay Formation, on the south side of the Minas Subbasin, and predominantly redbeds and basalt conglomerates, termed the McCoy Brook Formation, on the north side of the subbasin (Fig. 1). No post-basalt strata are preserved in outcrop in the Fundy or Chignecto subbasins.

\section{McCoy Brook Formation}

Post-basalt strata on the north side of the geographic Minas Basin are exposed to the south of the Portapique fault, along the coast from Clark Head east to Five Islands (Fig. 1) (Donohoe and Wallace, 1978, 1982; Keppie, 1979). These rocks were initially assigned to the Blomidon Shale Member of the Annapolis Formation by Powers (1916), who gave the name Five Island Volcanics to basalt conglomerates outcropping west of McKay Head. Klein (1962) considered the North Mountain Basalt headland at McKay Head as a separate older unit, the McKay Head Basalt, and correlated the overlying redbeds and basalt conglomerates with the revised Blomidon Formation. Liew (1976) first recognized the Jurassic age of outcrops on the north side of the basin and correlated them with the Scots Bay Formation, a usage followed by Stevens $(1980,1987)$, and Williams et al. (1985).
The designation of McCoy Brook Formation first appeared on maps (Donohoe and Wallace, 1978, 1982: Keppie, 1979) in reference to post-basalt sedimentary strata on the north side of the geographic Minas Basin and has been used subsequently by most researchers studying this unit. The name derives from the informal designation of a type section at McCoy Brook, which flows into the Minas Basin 400 m west of McKay Head (H. Donohoe, personal communication, 1987).

McCoy Brook strata comprise sandstones, mudstones, conglomerates, and breccias of fluvial, lacustrine, playa, sandflat, alluvial-fan, eolian, debris-flow, and talus origin (Hubert and Mertz, 1984; Olsen et al., 1989; Tanner and Hubert, 1991, 1992) exposed in fault-bounded sections with a maximum thickness of ca. $230 \mathrm{~m}$. Outcrops are limited almost entirely to cliffs along the north shore of the Minas Basin. A lower Jurassic age is supported by the stratigraphic relation to the underlying Hettangian age North Mountain Basalt, ichnotaxa including therapod and fabrosaurid dinosaurs (Olsen, 1981, 1988), semionotid and redfieldiid fish remains, and the osseus remains of synapsid, saurian and therapod reptiles (Olsen et al., 1987; Olsen, 1988). Palynology suggests an age range of Hettangian to Pliensbachian for this formation (Traverse, 1987).

The section exposed at McCoy Brook, accessible from the end of Two Island Road from Parrsboro, is the thickest single exposure of the formation, comprising $180+\mathrm{m}$ of nearly continuous strata, dipping west at 20 to $30^{\circ}$ (Figs. 3, 4). At this location, the McCoy Brook Formation consists of a 40 $m$ section (section $A$ ) to the east of McCoy Brook. The base of the section rests on the North Mountain Basalt at McKay Head. The top of the section is covered. Section B (68.5 m in thickness) is exposed immediately east of McCoy Brook and is separated from section C (71 m in thickness) by a reverse fault of undetermined offset. These west dipping strata comprise predominantly red beds of interbedded muddy sandstone and sandy mudstone, with subordinate fissile claystone 


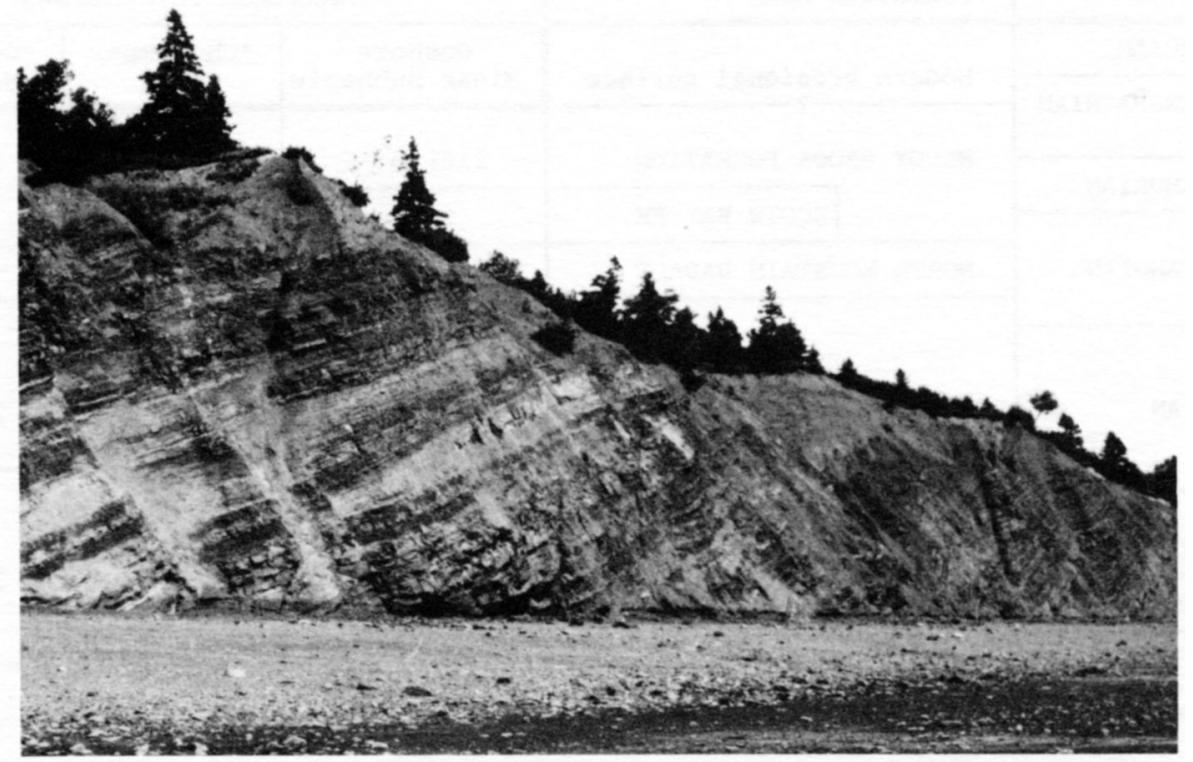

Fig. 3. Outcrop photo of the type section of the McCoy Brook Formation west of McCoy Brook (Section B - approximately 800 m west of McKay Head). West is to the left in the photograph.

MCKAY HEAD - SECTION A
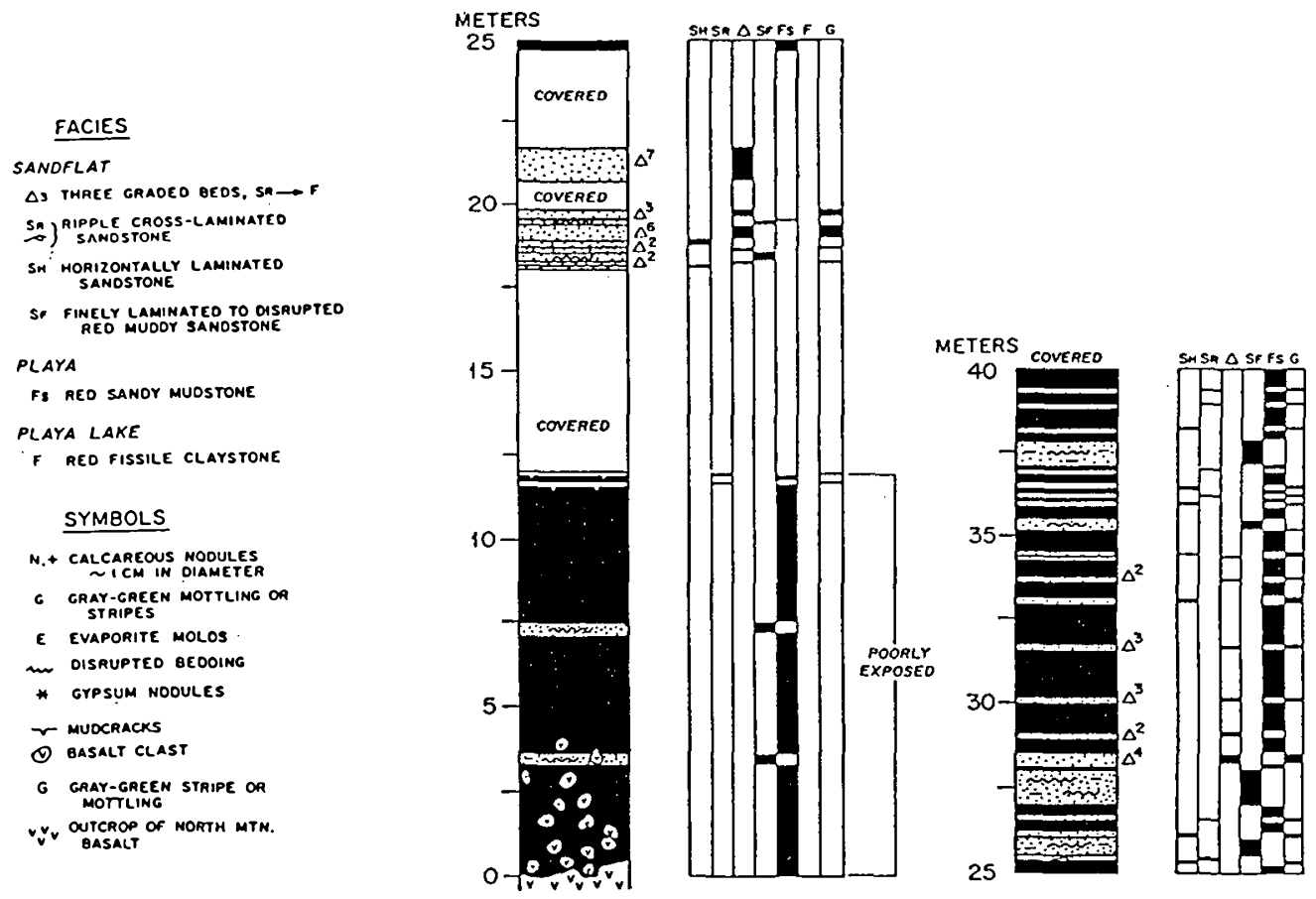

Fig. 4. Measured sections of the McCoy Brook Formation at the type location, west of McKay Head (see Fig. 1). Section A begins at the base of the formation on the North Mountain Basalt on the west flank of McKay Head and is covered east of the McCoy Brook ravine. Section B begins immediately to the west of McCoy Brook. Section C is west of and separated by a high-angle reverse fault from section $B$. Lithologic differences across the fault indicate that there is no repeat. 
MCKAY HEAD

Section $B$
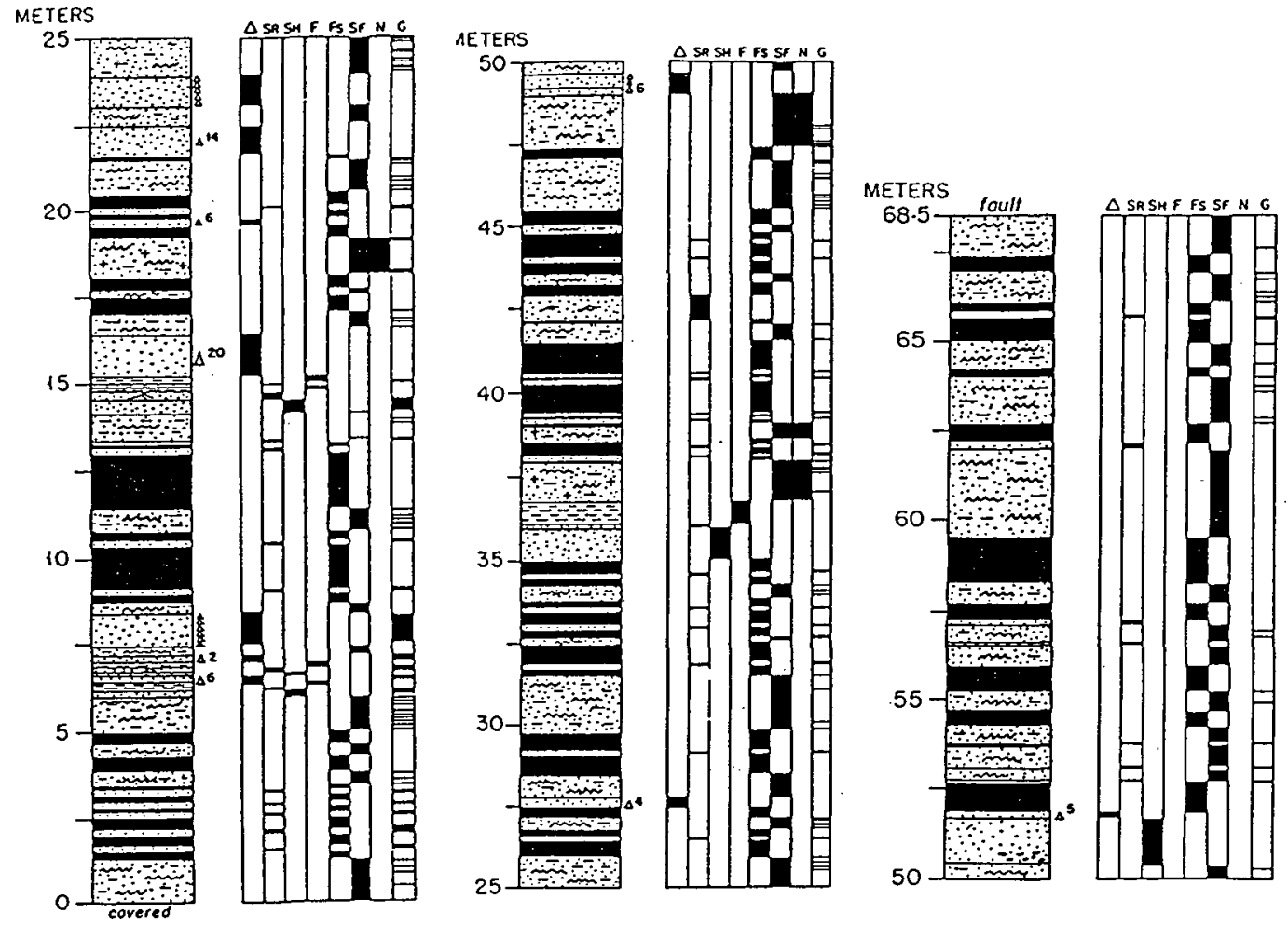

MCKAY HEAD

Section $C$
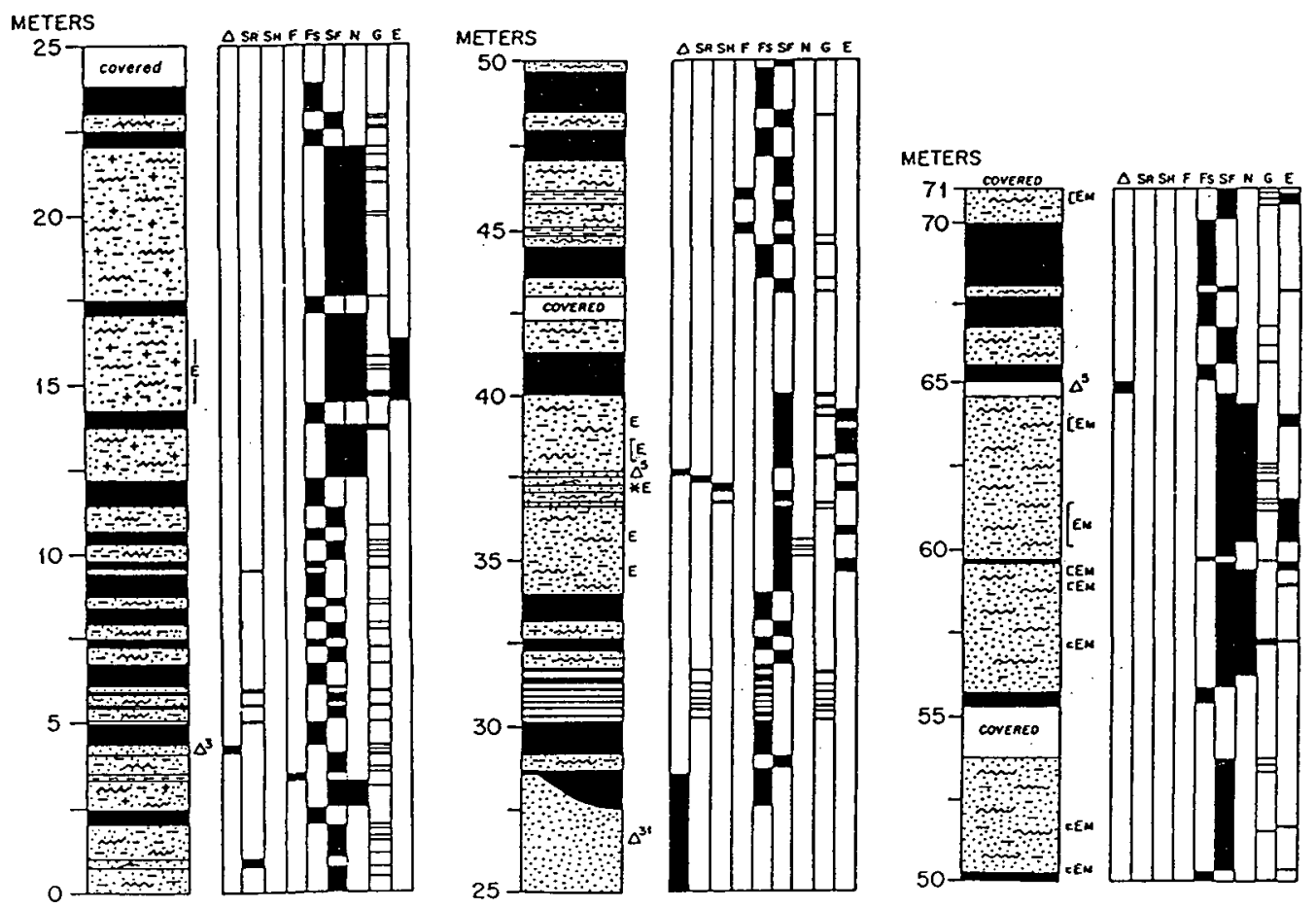

Fig. 4. Continued. 
and horizontally-laminated to ripple-laminated sandstone. Muddy sandstone beds range in thickness from 0.3 to 5.0 $\mathrm{m}$, and vary from massive to finely laminated to ripple crosslaminated, commonly displaying a sandpatch fabric (sensu Smoot and Olsen, 1988). Spherical to ovoid dissolution vugs occur in continuous horizons. Gypsum nodules occur locally near the top of the section (at $37 \mathrm{~m}$ in section C). Sandy mudstone beds, 0.1 to $5.0 \mathrm{~m}$ in thickness, are massive to finely laminated, with local desiccation cracks. The mudstones are interpreted as resulting from deposition of muds on a playa mudflat on the valley floor. Local progradation of alluvial fan lobes caused advance of sandflat facies over playa facies, resulting in deposition of finely laminated sands to graded sand-mud packages. Interstitial precipitation of ephemeral salts disrupted bedding features. Ephemeral lakes, in which clays were deposited, formed locally and ephemeral stream channels crossed the playa (Figs. 3, 4) (Tanner and Hubert, 1992). These facies are very similar to those of the Blomidon Formation below the North Mountain Basalt (Mertz and Hubert, 1990). Although different facies occur at other outcrop locations in the McCoy Brook Formation, the playa mudstone/sandflat sandstone facies is the most common. The McCoy Brook section, being the thickest exposure of these facies, is therefore appropriate as a type section.

Lacustrine strata of the McCoy Brook Formation occur at or just above the contact with the underlying basalt at several locations, but are best exposed northwest of Wasson Bluff in a section that onlaps the steeply dipping basalt surface (Figs. 5, 6). This location has been discussed by Olsen et al. (1989) and Olsen and Schlische (1990). The section comprises a basal coarse green (basaltic) sandstone, greybrown to green variegated sandy mudstone and siltstone with locally abundant semionotid fish scales and bones and interbedded lenses of basalt talus, and up to $30 \mathrm{~cm}$ of nodular weathering micritic limestone containing ostracodes and fish bones. The top of the section comprises grey to brown sandy mudstone of possible playa origin and fine grained cross-bedded sandstone of fluvial origin. Several of these units are sufficiently distinctive to be traceable for distances of hundreds of metres (Olsen and Schlische, 1990).

Synsedimentary extensional faulting along the north shore of the basin created a topography of graben and half-graben depressions (Olsen and Schlische, 1990; Tanner and Hubert, 1991). The lake beds accumulated as the graben and halfgraben subsided during initial deposition of the McCoy Brook Formation. The basalt sandstone at the base of the lacustrine section near Wasson Bluff resulted from wave erosion of the basalt surface on which the lake formed (Olsen et al., 1989) attesting to sufficient size of the lake for wave erosion. The tooth of a hybodont shark found in the lake beds (Olsen, 1988) also suggests a lake large enough to support predators. Deposition of the micritic limestone (wackestone to mudstone) probably represents maximum lake depth, suggested by the lack of terrigenous clastics.

\section{Extent of MCCoy Brook Equivalent STRATA}

Two offshore wells in the Fundy Subbasin have intersected McCoy Brook equivalent strata (Fig. 2). The Irving Chevron Cape Spencer \#79 penetrated $169 \mathrm{~m}$ of post-basalt sediments and recorded samples (cuttings) from roughly 90 $\mathrm{m}$ of section above the basalt. The Mobil Gulf Chinampas $\mathrm{N}-37$ logged samples from over $350 \mathrm{~m}$ of section above the basalt. Jurassic strata in both wells consist predominantly of interbedded red sandstones, siltstones and mudstones, calcareous and sporadically gypsiferous, indicating that the facies described at the type section of the McCoy Brook Formation are predominant offshore. An interesting observation is the occurrence of basalt in cuttings from the Cape Spencer well $25 \mathrm{~m}$ above the North Mountain Basalt, suggesting the presence of basalt conglomerates or breccias similar to those observed in onshore sections of the McCoy Brook Formation, interpreted as debris-flow and talus deposits (Tanner and Hubert, 1991). Seismic sections suggest that Jurassic sedimentary rocks overlying the North Mountain Basalt are substantially thicker in the depocenter of the Fundy Subbasin and may attain a thickness of over $3 \mathrm{~km}$ south of Grand Manan Island (Brown and Grantham, 1992).

\section{Scots Bay Formation}

Post-basalt sedimentary outcrops were first recognized in the Minas Subbasin by Ells (1894), who inferred a postTriassic age of the outcrops. The formation was subsequently studied by Haycock (1903) who attributed a marine origin. Powers (1916) named the formation and postulated a much larger original extent. The Scots Bay Formation has been subsequently studied by Klein $(1960,1962)$, Thompson (1974), Birney (1985), De Wet and Hubert (1989), Olsen et al . (1989) and others. The type section is at East Broad Cove in Kings County, Nova Scotia (Klein, 1962). Descriptions of Scots Bay sections, including the type location, have been published in De Wet and Hubert (1989) and Olsen et al. (1989). A detailed map of the outcrop locations is found in Brown and Grantham (1992).

The Scots Bay Formation is exposed along the shore of Scots Bay on the west side of the Blomidon Peninsula in six isolated structural depressions (Fig. 1). These depressions have been interpreted as circular collapse structures in the North Mountain Basalt by Stevens (1987). The outcrops lie directly on the surface of the North Mountain Basalt and range in thickness from $2 \mathrm{~m}$ to just over $9 \mathrm{~m}$ (De Wet and Hubert, 1989). Individual exposures extend laterally a distance of approximately $100 \mathrm{~m}$ to $200 \mathrm{~m}$.

The lithologies include red and green calcareous siltstone, crudely bedded, commonly silicified limestone, thickbedded chert, stromatolitic limestone, and brown, cross-bedded sandstone (De Wet and Hubert, 1989; Olsen et al., 1989). These strata, containing charophyte debris, fish bones, ostracodes, gastropods, and conchostracans, are interpreted 


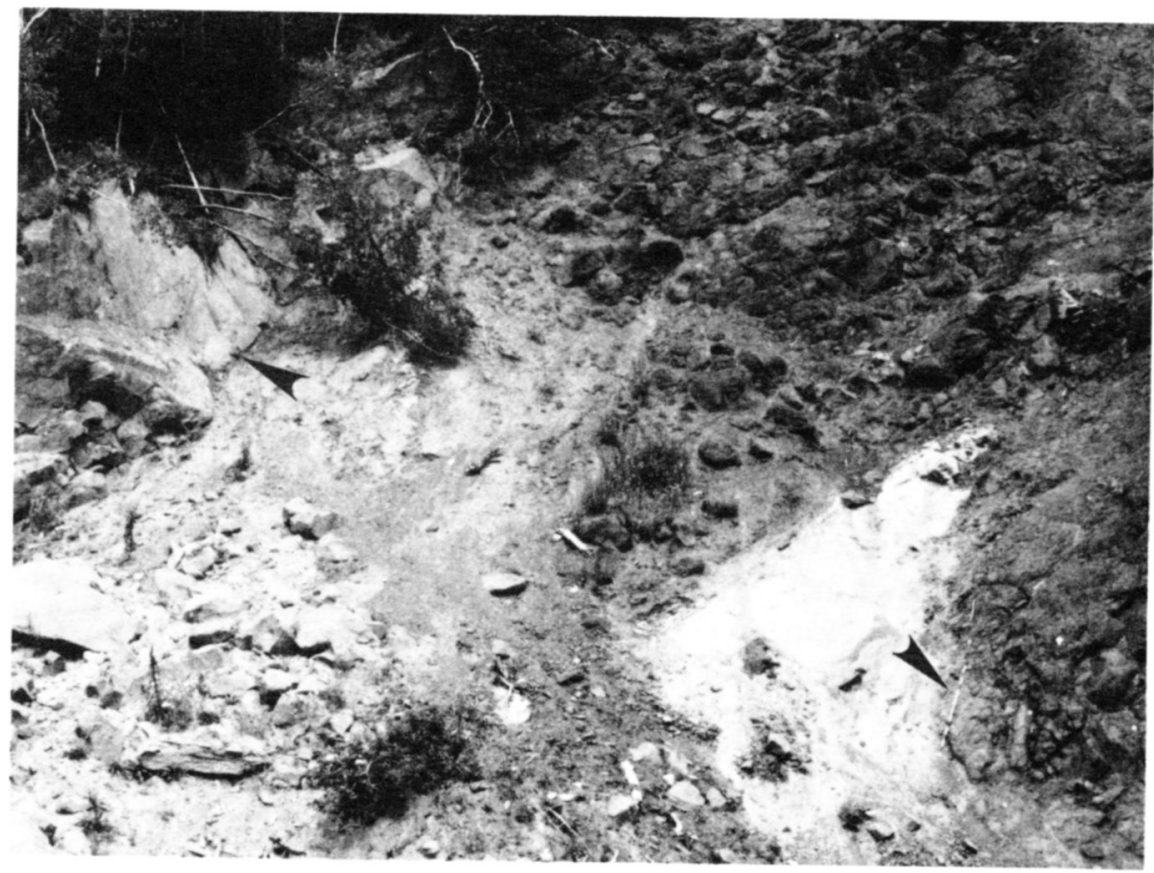

Fig. 5. Outcrop photo of lacustrine strata of the McCoy Brook Formation onlapping tilted surface of North Mountain Basalt west of Wasson Bluff. The arrow at the lower right indicates a $1.5 \mathrm{~m}$ staff at the contact of the sedimentary strata with the basalt. The upper left arrow points to the cross-bedded sandstones at the top of the measured section (Fig. 6).

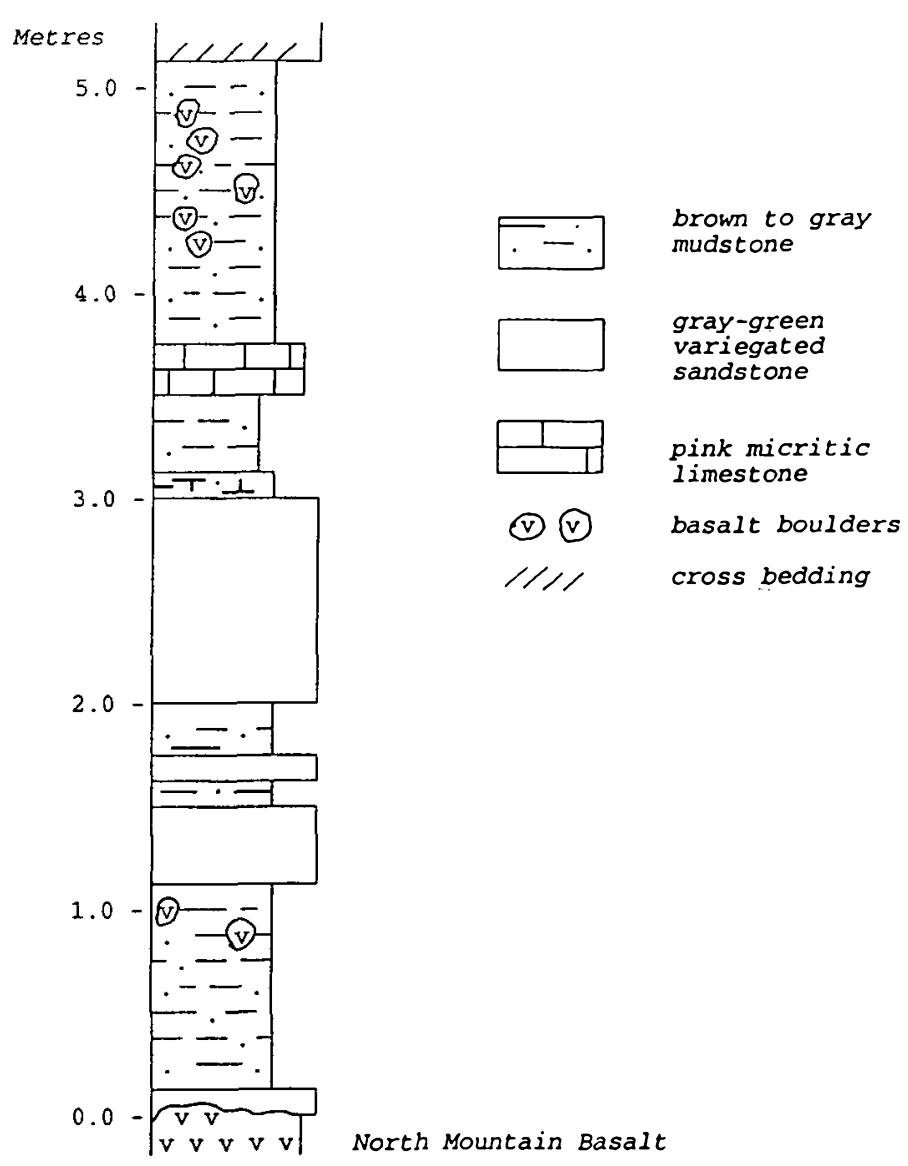

Fig. 6. Representative measured section of lacustrine strata of McCoy Brook Formation near Wasson Bluff in Figure 5. as the deposits of a shallow, oxygenated, oligotrophic to eutrophic lake (Birney, 1985; De Wet and Hubert, 1989). Although no age-specific forms have been found, a Hettangian age for the Scots Bay Formation is inferred from its position immediately above the basalt. Carbonate lithologies of packstone with varying terrigenous content, wackestone and mudstone suggest deposition in water depths ranging from shoreline to moderately deep offshore (Birney, 1985; De Wet and Hibert, 1989). Metre-scale cyclic variations in lithology and isotopic composition suggest periodic shrinkage and expansion of the lake (Suchecki et al., 1988). The cherts are attributed to hydrothermal vents on the lake floor (De Wet and Hubert, 1989).

This lake may or may not have been widespread across the rift valley. Good et al. (1994) and Good (1995) suggested, on the basis of the limited areal extent of the outcrops and the molluscan fauna, that Scots Bay deposition occurred in isolated ponds occupying small depressions on the basalt surface. This interpretation seems contradictory to the model of Birney (1985) and De Wet and Hubert (1989) of distinct shoreline and low energy lake bottom facies significantly isolated from clastic influx. Although the tiiickness and sequence of lithologies varies from outcrop to outcrop, De Wet and Hubert (1989) correlated one horizon between all of the sections, which are separated by a total of approximately $5 \mathrm{~km}$. Perhaps the variations between exposures resulted from variable relief on the basalt surfact: and variations in clastic input. Additionally, Olsen et al. (1989) suggested that Semionotus-bearing coprolites were proauced by a large coelacanth or shark, implying a body of water large enough to support predators. 


\section{Similarity OF Scots BaY AND MCCOY BROOK LACUSTRINE FACIES}

The outcrop of lacustrine facies in the McCoy Brook Formation at Wasson Bluff contains similar lithologies and, relative to the North Mountain Basalt, occupies the same stratigraphic position as the outcrops of the Scots Bay Formation. The most significant differences are the smaller proportion of limestone and the lack of chert in the Wasson Bluff section. The lack of chert in the McCoy Brook Formation most likely reflects a lack of adjacent hydrothermal vents as interpreted at Scots Bay. The lesser proportion of limestone in the McCoy Brook section may result from greater clastic input near the border fault. The lacustrine fauna of the McCoy Brook Formation, consisting of semionotid fish remains and darwinulid ostracodes, is also common to the Scots Bay Formation (Olsen, 1988). This evidence suggests that the lacustrine strata observed at Wasson Bluff and Scots Bay were deposited at approximately the same time under similar lacustrine conditions, if not in a single large lake.

\section{Discussion}

The equivalence of these formations is demonstrated by stratigraphic position and lithology, although the overall character of post-North Mountain Basalt deposition is clearly dominated by the playa mudstone/sandflat sandstone facies that comprises the MoCoy Brook type section and appears to persist offshore. The evidence suggests that these strata should be regarded as a single formation. Additionally, the factor of mappability favours including the Scots Bay outcrops, which are of very limited aerial extent, within the mappable McCoy Brook Formation. These considerations are sufficiently strong to outweigh publication priority of the name Scots Bay Formation and permit revision (Salvador, 1994). The name McCoy Brook Formation is here duly proposed for outcrops of Jurassic sedimentary strata in the Minas Subbasin deposited after eruption of the North Mountain Basalt. It is further proposed that this designation extend into the offshore to include strata of similar lithology and stratigraphic position in the entire Fundy Rift Basin.

The lacustrine facies that comprise the Scots Bay outcrops and the Wasson Bluff section of the McCoy Brook Formation appear to be a distinctive and equivalent basal member of this formation. The name Scots Bay Member is here duly proposed for this subdivision of the McCoy Brook Formation. The type section of the member is at East Broad Cove, previously regarded as the type section for the former Scots Bay Formation. These revisions are consistent with the procedures of the North American Code of Stratigraphic Nomenclature (NACSN, 1983) and the International Stratigraphic Guide (Salvador, 1994).

\section{ACKNowledgements}

The concepts in this paper were more fully developed by helpful discussions with D. Brown, P. Olsen and R. Schlische. M.J. Verrall was kind enough to provide access to well cut- tings. This manuscript was substantially improved by the thoughtful reviews of P. Stringer and $H$. van de Poll.

BiRney, C.C. 1985. Sedimentology and petrology of the Scots Bay Formation (Lower Jurassic), Nova Scotia, Canada. M.S. thesis, University of Massachusetts, Amherst, 325 p.

Brown, D.E. and Grantham, R.G. 1992. Fundy Basin Rift Tectonics and Sedimentation. Field Excursion A-3: Guidebook, Geological Association of Canada, Mineralogical Association of Canada, Atlantic Geoscience Society, Wolfville, Nova Scotia.

De Wet, C.C.B. and Hubert, J.F. 1989. The Scots Bay Formation, Nova Scotia, Canada, a Jurassic carbonate lake with silica-rich hydrothermal springs. Sedimentology, 36, pp. 857 873.

Donohoe, H.V. and Wallace, P.I. 1978. Geology map of the Cobequid Highlands. Nova Scotia Department of Mines, Preliminary Map 78-1, scale 1:50,000.

.....- 1982. Geological map of the Cobequid Highlands. Nova Scotia Department of Mines and Energy, Map 82-7, scale $1: 50,000$.

ELLS, R.W. 1894. Notes on recent sedimentary formation on the Bay of Fundy coast. Transactions of the Nova Scotia Institute of Science, 8, pp. 416-419.

Good, S.C. 1995. Molluscan paleoecological associations of the Newark Supergroup basins as paleoenvironmental indicators. Geological Society of America, 1995, Abstracts with Programs, 27(1), p. 49.

Good, S.C., Yenik, L.A., Olsen, P.E., and McDonald, N.G. 1994. Non-marine molluscs from the Scots Bay Formation, Newark Supergroup (Early Jurassic), Nova Scotia: taxonomic assessment and paleoecologic significance. Geological Society of America, 1994, Abstracts with Programs, 26(3), p. 20.

Greenough, J.D. 1995. Mesozoic rocks. In Geology of the Appalachian-Caledonian Orogen in Canada and Greenland. Edited by $\mathrm{H}$. Williams. Geological Survey of Canada, No. 6, pp. $567-600$.

Haycock, E. 1903. Fossils, possibly Triassic, in glaciated fragments in the Boulder clay of Kings County, Nova Scotia. Proceedings and Transactions of the Nova Scotia Institute of Science, 10, pp. 376-378.

Hodych, J.P. and Dunning, G.R. 1992. Did the Manicouagan impact trigger end-of-Triassic mass extinctions? Geology, 20, pp. 51-54.

HUbert, J.F. and ForlenzA, M.F. 1988. Sedimentology of braidedriver deposits in Upper Triassic Wolfville redbeds, southern shore of Cobequid Bay, Nova Scotia, Canada. In Triassic-Jurassic rifting: continental breakup and the origin of the Atlantic passive margins, part A. Edited by W. Manspeizer. Elsevier, Amsterdam, pp. 231-248.

Hubert, J.F. and MerT2, K.A. 1984. Eolian sandstones in Upper Triassic-Lower Jurassic red beds of the Fundy basin, Nova Scotia. Journal of Sedimentary Petrology, 54, pp. 798-810.

KLEIN, G. deV. 1960. Stratigraphy, sedimentary petrology, and structure of Triassic sedimentary rocks, Maritime Provinces, Canada. Ph.D. thesis, Yale University, New Haven, Connecticut, 262 p.

-...- 1962. Triassic sedimentation, Maritime Provinces, Canada. Geological Society of America Bulletin, 73, pp. 1127-1146.

KEPPIE, J.D. 1979. Geological map of the province of Nova Scotia. Nova Scotia Department of Mines and Energy, Map 79-1.

LIEw, M.Y.C. 1976. Structure, geochemistry, and stratigraphy of Triassic rocks, north shore of Minas Basin, Nova Scotia. 
Unpublished M.Sc. thesis, Acadia University, Wolfville, Nova Scotia, $181 \mathrm{p}$.

Mertz, K.A. and Hubert, J.F. 1990. Cycles of sand-flat sandstone and playa-lacustrine mudstone in the Triassic-Jurassic Blomidon redbeds, Fundy rift basin, Nova Scotia: implications for tectonic and climatic controls. Canadian Journal of Earth Sciences, 27, pp. 442-451.

North American Commission on Stratigraphic Nomenclature. 1983. North American Stratigraphic Code. American Association of Petroleum Geologists Bulletin, 67, pp. 841-875.

OLSEN, P.E. 1981. Comment and reply on 'eolian dune field of Late Triassic age, Fundy basin, Nova Scotia.' Geology, 9, pp. 557-559.

1988. Paleontology and paleoecology of the Newark Supergroup (early Mesozoic, eastern North America). In Triassic-Jurassic rifting: continental breakup and the origin of the Atlantic passive margins, part A. Edited by W. Manspeizer. Elsevier, Amsterdam, pp. 185-230.

Olsen, P.E. and Schlische, R.W. 1990. Transtensional arm of the early Mesozoic Fundy rift basin: penecontemporaneous faulting and sedimentation. Geology, 18, pp. 695-698.

Olsen, P.E., Shubin, N.H., and Anders, M.H. 1987. New Early Jurassic tetrapod assemblages constrain Triassic-Jurassic tetrapod extinction event. Science, 237, pp. 1025-1029.

Olsen, P.E., Schlische, R.W., and Gore, P.J.W. 1989. Tectonic, depositional, and paleoecological history of early Mesozoic rift basins, eastern North America. Guidebook to International Geological Congress Field Trip T-351, 174 p.

Powers, S. 1916. The Acadian Triassic. Journal of Geology, 24, pp. 1-16, 105-122, 254-268.

SAlvador, A. (Editor) 1994. International stratigraphic guide: a guide to stratigraphic classification, terminology, and procedure (2nd edition). International Union of Geological Sciences and Geological Society of America, Boulder, Colorado, 214 p.

SMOот, J.P. 1991. Sedimentary facies and depositional environments of early Mesozoic Newark Supergroup basins, eastern North America. Palaeogeography, Palaeoclimatology, Palaeoecology, 84, pp. 369-423.

Smoot, J.P. and Olsen, P.E. 1988. Massive mudstones in basin analysis and paleoclimatic interpretation of the Newark Supergroup. In Triassic-Jurassic rifting: continental breakup and the origin of the Atlantic passive margins, part A. Edited by W. Manspeizer. Elsevier, Amsterdam, pp. 185-230.

Stevens, G.R. 1980. Mesozoic vulcanism and structure - northern Bay of Fundy region, Nova Scotia. Geological Association of Canada and Mineralogical Association of Canada, Field Trip Guidebook, 41 p.

.....- 1987. Jurassic basalts of northern Bay of Fundy region, Nova Scotia. In Centennial. Field Guide, Volume 5. Edited by D.C. Roy. Northeastern Section of the Geological Society of America, pp. 415-420

SuCHECKI, R.K., Hubert, J.F., and De Wet, C.C.B. 1988. Isotopic imprint of climate and hydrogeochemistry on terrestrial strata of the Triassic-Jurassic Hartford and Fundy rift basins. Journal of Sedimentary Petrology, 58, pp. 801-811.

TANNER, L.H. and HuBERT, J.F. 1991. Basalt breccias and conglomerates of the Lower Jurassic McCoy Brook Formation, Fundy basin, Nova Scotia: differentiation of talus and debris-flow deposits. Journal of Sedimentary Petrology, 61, pp. 15-27.

- 1992. Depositional facies, palaeogeography and palaeoclimatology of the Lower Jurassic McCoy Brook Formation, Fundy rift basin, Nova Scotia. Palaeogeography, Palaeoclimatology, Palaeoecology, 96, pp. 261-280.

Thompson, J.P. 1974. Stratigraphy and geochemistry of the Scots Bay Formation, Nova Scotia. M.Sc. thesis, Acadia University, Wolfville, Nova Scotia, 358 p.

Traverse, A. 1987. Pollen and spores date origin of rift basins from Texas to Nova Scotia as early Late Triassic. Science, 236, pp. 1469-1472.

Williams, G.L., Fyffe, L.R., Wardle, R.J., Colman-Sadd, S.P., and BOEHNER, R.C. (Editors) 1985. Lexicon of Canadian Stratigraphy: Volume VI - Atlantic Region. Canadian Society of Petroleum Geologists, 572 p.

Withiack, M.O., Olsen, P.E., and Schlische, R.W. 1995. Tectonic evolution of the Fundy rift basin, Canada: evidence of extension and shortening during passive margin development. Tectonics, 14 , pp. $390-406$.

Editorial Responsibility : R.K. Pickerill 